\title{
The Role of Elasmobranchs in the Cantabrian Sea Shelf Ecosystem and Impact of the Fisheries on Them
}

\author{
F. Sánchez, C. Rodríguez-Cabello and I. Olaso \\ Instituto Español de Oceanografía \\ P. O. Box 240, Santander, Spain
}

Sánchez, F., C. Rodríguez-Cabello, and I. Olaso. 2005. The Role of Elasmobranchs in the Cantabrian Sea Shelf Ecosystem and Impact of the Fisheries on Them. J. Northw. Atl. Fish. Sci., 35: 467-480. doi:10.2960/J.v35.m496

\begin{abstract}
Elasmobranchs apparently play an ecological role of relevance in the demersal community of the Cantabrian Sea. Using biomass indices obtained from bottom trawl surveys, the most significant elasmobranch species in the continental shelf ecosystem are described. By combining their spatial distribution with multivariate analysis, including other fish species, it is possible to place them within the communities that structure the ecosystem. Considering all the fish species inhabiting the continental shelf and applying a trophodynamic model, which incorporates biomass, production, biological parameters, feeding diets and catches and discards of the fisheries, the trophic level of the main elasmobranch groups and their relationship with others species inhabiting the same area are obtained. Also an estimation of the impact of the different fisheries (gears) that operate in the study area is made. Finally, some time-spatial simulations of the consequences of some management measurements affecting elasmobranch populations such fishery closed areas, have been performed. The results of these simulations are validated in situ by carrying out experiments in a closed area located in the central Cantabrian Sea shelf.
\end{abstract}

Key words: Cantabrian Sea, catshark, ecopath, ecosystem dynamics, fishery impact, ray

\section{Introduction}

The Cantabrian Sea area is the subtropical/ boreal transition zone of the Eastern Atlantic. Typical temperate-water species from the south occur together with those of northern origin and, consequently, high biodiversity indices occur in comparison with adjacent areas (Olaso, 1990; Sánchez, 1993; OSPAR, 2000). In addition, the topographical complexity and a wide range of substrates on its continental shelf result in many different types of habitats. The inner shelf (depth $<100 \mathrm{~m}$ ) has mainly rocky or sandy substrate, whereas the outer shelf has predominantly muddy substrate. The production of the area is greatly influenced by a seasonal coastal upwelling (spring and summer) and hydrographic mesoscale activity along the northwestern shelf-break. This is a consequence of winter fluxes from the warm poleward current (also known as the "Navidad Current"), which results in a convergent front at the boundary between coastal and oceanic waters (OSPAR, 2000; Sánchez and Gil, 2000). These produce a regular pattern of hydrographic conditions throughout the year characterized by winter mixing and summer stratification, with phytoplankton blooms occurring during the transition periods. This seasonal pattern has a significant effect on the dynamics of the ecosystem.
This diversity is reflected in the biological richness of the region that includes many species of commercial interest. The fisheries, which have been operating for centuries, have a major effect on the structure and dynamics of the Cantabrian Sea ecosystem (Sánchez and Olaso, 2004). They have become more industrialised over the past 50 years, with the catch reaching about 200 000 tons per year. Trawlers fish on the muddy bottoms of the shelf, whereas longliners operate mainly on the shelfbreak bottoms and gillnets are used on rocky grounds near the coast and shelf-break.

Elasmobranchs are well represented on the continental shelf of the Cantabrian Sea, particularly demersal species (Sánchez, 1993; Sánchez et al., 1995, 2002). Bottom trawl surveys carried out in this region and the main fisheries themselves suggest that elasmobranchs play an important role in the ecosystem; these species are relatively abundant in all types of available habitat. In the present study, an attempt is made to describe the relationships among the main elasmobranchs groups that inhabit the shelf, and the relationships between these groups and the rest of the species inhabiting the shelf. For this purpose, all available elasmobranch information, such as biomass index, spatial and bathymetrical distribution, biological parameters, food preferences, catches 
and discards, has been used and joined with other components of the system, in a mass-balance model of trophic interactions.

\section{Material and Methods}

The Cantabrian Sea is considered as the southern region of the Bay of Biscay. However, for practical purposes of the present study, this zone is considered in its wider meaning (ICES Division VIIIc), which includes the Galician shelf to the north of Cape Finisterre (at latitude $43^{\circ} \mathrm{N}$ ) and is the upper limit of the subtropical Lusitanic area (Fig. 1). Division VIIIc has some relatively homogeneous biogeographical characteristics in relation to adjacent areas and fishing statistics and information are available from the evaluation of stocks carried out by the ICES stock assessment working groups, which were indispensable for developing the model. In the present study, we refer to the neritic area of the Cantabrian Sea, with a total continental shelf surface of about 16000 $\mathrm{km}^{2}$, and the neighbouring oceanic area.

\section{The Model}

The Ecopath (version 4.0) model was applied to produce a balanced steady-state description of the Cantabrian Sea shelf ecosystem. The Ecopath model combines estimates of biomass and food consumption of the various components (species or groups of species) in an aquatic ecosystem with an analysis of flows between the ecosystem elements (Polovina, 1984 and further developed by Christensen and Pauly, 1992, 1993). The energy balance of each trophic group is given by the basic equation:

\section{Consumption $=$ Production \\ + Respiration+ Unassimilated food}

The production of each trophic group is balanced by its catches, its predation by other trophic groups in the system, its biomass accumulation, its exports from the system, and other mortality. The ecosystem is modelled using a set of simultaneous linear equations (one for each group $i$ in the system):

$$
P_{i}=Y_{i}+B_{i} \times M 2_{i}+E_{i}+B A_{i}+P_{i} \times\left(1-E E_{i}\right)
$$

where $P_{i}$ is the total production rate of $(i), Y_{i}$ is the total fishery catch rate of $(i), B_{i}$ the biomass of the group, $M 2_{i}$ is the total predation rate for group $(i), E_{i}$ the net migration rate (emigration - immigration), $B A_{i}$ is the biomass accumulation rate for $(i)$, whereas $M O_{i}=P_{i} \times\left(1-E E_{i}\right)$ is the "other mortality" rate for $(i)$.

This can also be expressed as:

$$
\begin{gathered}
B_{i} \times(P / B)_{i} \times E E_{i}-\sum B_{j} \times(Q / B)_{j} \\
\times D C_{j i}-Y_{i}-E_{i}-B A_{i}=0
\end{gathered}
$$

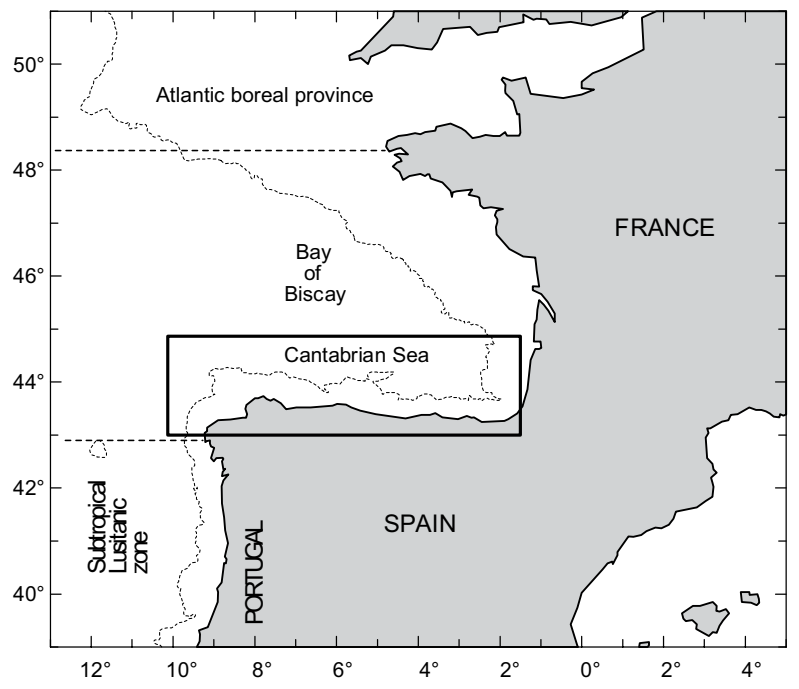

Fig. 1. The Cantabrian Sea area as defined in the ecosystem model.

where $(P / B)_{i}$ is the production/biomass ratio (equal to the instantaneous rate of total mortality $Z$ in steady-state systems) of $(i) ; B_{j}$ is the biomass of predator $j ;(Q / B)_{j}$ is the consumption/biomass ratio of predator $j ; D C_{j i}$ is the fraction of prey $(i)$ by weight in the average diet of predator $j$ and $E E_{i}$ is the ecotrophic efficiency of $(i)$ : expressing the fraction of total production consumed by predators or caught by a fishery.

A classification of species according to their prey was carried out as a first step. On this basis, and to construct the mass-balance model, 28 trophic groups were defined: 15 groups of fish, 6 of invertebrates, 5 of plankton, 1 of detritus and 1 of fishery discards. In each group, we considered species of similar size, habitat, diets, consumption rates, mortality, and production rates. All the available data of biomass, landings and discards were converted into the same unit $\left(t\right.$ per $\left.\mathrm{km}^{-2}\right)$ expressed as wet weight. Estimates of biomass, mortality, consumption and ecotrophic efficiency by different methods for each trophic group were used in the model (Sánchez and Olaso, 2001; 2004). All the input data used in the present study are available for 1994, which is the first year for available discards data. The pedigree routine (Pauly et al., 2000), that summarises the quality of the data by categorizing the different input sources used to construct the model, gave a good pedigree index of 0.67 .

\section{Biomass and Production Estimates}

Different and complementary sources of biomass have been used in the analysis. On the one hand, biomass estimates of all the species are based on the bottom trawl 
surveys carried out in this area, applying the swept area method (Sánchez et al., 1995; 2002). On the other hand, estimates of various quantities for the main commercial species are taken from reports of their respective stock assessments (ICES, MS 2002b, MS 2002c).

To simplify the model, and because a full data set is not available for all elasmobranchs species, only two trophic groups of elasmobranchs were considered. Catshark and rays were placed in separate trophic groups on the basis of their different food preferences. Smallspotted catshark (Scyliorhinus canicula) comprises $80 \%$ of the catshark group biomass. Other species in this group were small deep-water sharks, such as the blackmouth catshark (Galeus melastomus), the birdbeak dogfish (Deania calceus) and the velvet belly lantern shark (Etmopterus spinax). At least eight species of rays occur in the area (Sánchez et al., 1995; 2002) of which the most abundant is the thornback ray (Raja clavata) (50\% of the biomass in the trophic group) followed by R. montagui and Leucoraja naevus.

Total biomass of catshark and ray species obtained from bottom trawl surveys applying the swept area method (Sánchez et al., 1995; 2002) was underestimated because only an unknown percentage of the population is accessible to the gear. However, a comparison made between the biomass estimated by stock assessments and by survey index of similar behaviour demersal species, like hake (Merluccius merluccius) and megrim (Lepidorhombus whiffiagonis), makes it possible to predict that the survey only estimates $10-15 \%$ of the total biomass. Assuming the same proportion for catshark and rays results in a total biomass of 8250 tons and 5250 tons, respectively, in the ICES Division VIIIc. Recently a preliminary assessment of $S$. canicula (ICES Division VIIIc), R. clavata (Divisions IVb and IVc) and L. naevus (Divs. VIIIghj and VIIIab) has been undertaken by the DELASS project (ICES, MS 2002a). Despite the difficulties associated with the data requirements and the methods used, the total biomass of $S$. canicula estimates from virtual population analysis (VPA) outputs in 1994 for the ICES Division VIIIc was 5933 tons. These estimates (adding a 20\% corresponding to the other species of small sharks to complete the catshark trophic group) are very close to those estimated from the survey index.

Total mortality $(Z)$ of catshark, and rays in this area is unknown. However, based on current knowledge of these species and by comparing data from the present study with available data from other areas, values of $Z$ $=0.25$ for catshark and $Z=0.30$ for rays were used in the model for the PB (production/biomass ratio). The $Z$ value for the rays group applied in the present study is lower than the $Z$ values of 0.58 for $R$. clavata, 0.54 for $R$. montagui and 0.58 for L. naevus available for the North Sea. These species are heavily exploited in the North Sea and support a higher fishing mortality than in the region of the present study (Walker, 1998).

\section{Feeding}

The links between groups were their feeding preferences; the information needed to create the diet matrix was taken from different sources (Sánchez and Olaso, 2004). A quantitative analysis was undertaken of the stomach contents from 10200 fish of 36 species in the study area. The species selected constituted a significant percentage $(90 \%)$ of the demersal fish biomass. To obtain an appropriate representation of the annual diet of the fish, seasonal changes in diet that occur in many species was also considered,. This was based on analysis of the stomach contents from specimens caught in spring and autumn surveys. The elasmobranch diet matrix included stomach contents from a total of 4348 S. canicula, 794 G. melastomus, and 1734 rays stomachs, which were analysed over the study period (Olaso et al., 2004; Velasco et al., 2002). The catshark component consumes mainly decapod crustaceans, blue whiting and discards. The food preferences of rays, being more specialist than catshark, include principally brachiura and natantia crustaceans.

\section{Fisheries}

The statistical data for fisheries landings were provided by the ICES stock assessment working groups and by the Instituto Español de Oceanografia (IEO) Fishery Database team. The data were subsequently summarised and combined by trophic group (Sánchez and Olaso, 2004). Landings data for each elasmobranch species were not available because most of these species have low commercial value and were taken as by-catch, which implies that traditionally these species were landed together in a single category. Considerable effort has been recently made in collecting and improving data from elasmobranch fisheries, particularly from 1996 to 2001 (one of the main objectives of DELASS project). The data of landings by fishing gear used in the present paper have been improved from the previously published original model (Sánchez and Olaso, 2004); however, no information is available for 1994 so estimates have been made. Landings of $S$. canicula remain more or less stable at about 200 tons showing an increasing trend in the last years; in 1994 a total of 250 tons was estimated, of which 215 tons belonged to trawl catches. In the case of rays, an increasing trend is also observed in the last 
years, showing fluctuations between years; an estimate of 450 tons landed (405 tons for trawl) was assigned for 1994.

The highest catshark landings are from bottom trawl (75\%), followed by longline (21\%) and gillnet (3\%); some landings from purse seine and traps have also been occasionally recorded. Rays data from the fishery indicate that the most abundant species are $R$. montagui, $R$. clavata and $L$. naevus and the highest landings come from trawl (81\%), followed by gillnet (11\%) and longline (8\%); some landings with purse seine or traps have also been occasionally recorded (Rodríguez-Cabello et al., 2004).

\section{Discards}

Mainly sea birds, fish and benthic scavenger species consume discards ( $20 \%$ of the total catches in the Cantabrian Sea). In the present study, information was based on the results of the discard sampling programme which covered the activities of some of the most important Spanish fleets during 1994 in ICES Division VIIIc, such as trawlers, gillnets, longliners, and purse seiners (Pérez et al., 1996). Blue whiting (Micromesistius poutassou) and horse mackerel (Trachurus trachurus) were the main species discarded. It has been estimated that 6149 and 5040 tons of these two species, respectively, were discarded during 1994. Other heavily discarded trophic groups were $S$. canicula, some of which (78\%) survive the process (Rodriguez-Cabello et al., 2004), include benthic invertebrate carnivores, small demersal fish and other invertebrates. To determine the species that benefit from discards, some studies have been carried out in the area (Olaso et al., 1998; Olaso et al., 2002a), and their results have been included in the present model.

\section{Mixed Trophic Impacts}

The mixed trophic impact (MTI) of different trophic groups and fisheries on other groups is obtained using the Leontief economic matrix routine implemented in Ecopath, following the subsequent development described by Ulanowicz and Puccia (1990). This analysis quantifies the direct and indirect interactions in a balanced system. The MTI for living groups is calculated by constructing a matrix, where the $i, j^{\text {th }}$ element representing the interaction between the impacting group $i$ and the impacted group $j$ is

$$
M T I_{i j}=D C_{i j}-F C_{j, i}
$$

where $D C_{i j}$ is the diet composition term expressing how much $j$ contributes to the diet of $i$, and $F C_{j, i}$ is a host composition term giving the proportion of the predation on $j$ that is due to $i$ as a predator. When calculating the host compositions, the fishing fleets are included as "predators". The mixed trophic impact routine gives an idea of how important the different fisheries are for the trophic dynamics of the system.

\section{Model Simulations}

We use the recent expansions of the Ecopath approach (Ecosim and Ecospace) to simulate changes in fishing pattern and intensity through time in an ecosystem framework. Ecosim is a time-dynamic simulation tool for studying fisheries policy options (Walters et al., 1997; Pauly et al., 2000). Ecosim includes biomass and size structure dynamics: mixed differential and difference equations and use of mass-balance assumptions for parameter estimation. Time patterns of biomass and equilibrium system responses under different exploitation regimes are predicted by these differential equations. Ecospace is a mesoscale spatial simulation tool for predicting spatial patterns and runs the Ecopath model through Ecosim to check the behaviour of the ecosystem. Numerical approximation by linearisation, and matrix exponential solution method generate projection predictions towards spatial equilibrium. Walters et al. (MS 1998) describe all the functions used in Ecospace simulations. To explore the simulation capacity of Ecospace we defined a base-map of central area of the Cantabrian Sea with five habitats: oceanic, break shelf, outer shelf, inner shelf and coastal waters. We also define the habitat preferences of trophic groups, based in Sánchez (1993) and Sánchez and Serrano (2003), and gears and the movement rates and vulnerability in bad habitats of the 26 living trophic groups.

To consider whether the simulations of the management measures using the trophodynamic model are realistic, we studied the recovery rates after trawl disturbance in an existing restricted area. Fishery policy establishes that bottom trawl gears are forbidden to work on fishing grounds $<100 \mathrm{~m}$ deep in the Cantabrian Sea. To exclude illegal trawling operations, concrete blocks (artificial reefs) were placed by local fisheries authorities on some of $<100 \mathrm{~m}$ soft grounds. To estimate the effect of this management measure, a study was carried out in the Llanes area (Asturias, central Cantabrian Sea), where in 1993 artificial reefs were placed. A historical series of bottom trawl surveys data were analysed, from 1983 to the present, to determine whether the differences found between the period before and the period after the date of fisheries exclusion from this area were significant. After 1993, we used bottom trawl surveys in a zone free of blocks not used by trawlers, included in the Llanes area to obtain information of the impact of the management measure. We assumed for the present study that the surface occupied by concrete blocks $(<0.02 \%)$ was irrelevant to modify the soft-ground community structure. 


\section{Results and Discussion}

The main elasmobranch species that inhabit the continental shelf of the Cantabrian Sea, based on the bottom trawl survey index (years 1997-99) are shown in Table 1. Scyliorhinus canicula is particularly abundant in the study area during the last years, being the fifth species in biomass after blue whiting, horse mackerel, hake and sea bream (Pagellus acarne) (Sánchez et al., 2002). The two most abundant catshark species $-S$. canicula and G. melastomus - show similar trends in their abundance pattern throughout the historical series (Fig. 2), which suggests that both species have similar environmental requirements. S. canicula inhabits shallower waters and it is representative of the inner shelf community; $G$. melastomus is found in deeper waters of the outer shelf community (Sánchez, 1993; Sánchez and Serrano, 2003). Considering that their food preferences are not very different (Olaso et al., 2004), both species have been included in the same trophic group for the model analysis. The rays $R$. clavata, $R$. montagui and L. naevus contribute a great proportion to the total biomass of the rays group (Table 1). They all show increasing trends in their abundance indices during the last 5 years of the time series (Fig. 2).

Elasmobranchs are well represented in the main fish communities described on the continental shelf of the Cantabrian Sea (Sánchez, 1993) and, moreover, some of them contribute to define the structure of these communities (Sánchez and Serrano, 2003). The rays $R$. clavata and $R$. montagui belong to the group of species that define the structure of the coastal community and $S$. canicula is one of the main species in the inner shelf community. The fish assemblage that comprises the outer shelf is structured, among other species, by G. melastomus and the shelf break by deep-water sharks such as E. spinax and D. calceus. Data from studies of these fish communities have been used to assign the habitat preferences (Table 1) in the spatial-temporal simulations carried out with Ecospace.

\section{Trophodynamic Model}

A summary of the input parameters for the balanced trophodynamic model is given in Table 2 together with some of the parameters estimated using Ecopath. The total biomass sustained by the ecosystem was estimated at 226 tons per $\mathrm{km}^{2}$, which corresponded to $49.5 \%$, $27.3 \%$ and $23.2 \%$ for the pelagic, demersal and benthic domains, respectively. This evidence the great importance of the bottom communities and benthic producers in the area. Tuna (4.71), large hake (4.77) and anglerfish (Lophius sp.) (4.80) showed the highest trophic level in their respective domains. Due to their scavenger and opportunistic habits the two groups of elasmobranchs

TABLE 1. Main species of elasmobranchs caught during the groundfish surveys ordered by biomass indices $(\mathrm{kg} / 30 \mathrm{~min}$. haul from $1997-99$ period) and percentage of participation in each trophic group in the trophodynamic model $(x=<1 \%)$. The habitat preferences were used in the Ecospace spatial-temporal simulations.

\begin{tabular}{|c|c|c|c|c|c|c|}
\hline \multirow[b]{2}{*}{ Family } & \multirow[b]{2}{*}{ Species } & \multicolumn{2}{|c|}{ Abundance indices } & \multicolumn{2}{|c|}{ Trophic group } & \multirow[b]{2}{*}{ Habitat preferences } \\
\hline & & $\overline{\mathrm{kg} / \mathrm{haul}}$ & No./haul & Catshark & Rays & \\
\hline Scyliorhinidae & Scyliorhinus canicula & 3.093 & 10.396 & $80 \%$ & & Inner and middle shelf \\
\hline Rajidae & Raja clavata & 0.999 & 0.926 & & $50 \%$ & Coastal and inner shelf \\
\hline Scyliorhinidae & Galeus melastomus & 0.600 & 4.942 & $15 \%$ & & Outer shelf \\
\hline Rajidae & Raja montagui & 0.565 & 0.664 & & $30 \%$ & Coastal and inner shelf \\
\hline Squalidae & Squalus acanthias & 0.369 & 0.085 & $x$ & & Middle and outer shelf \\
\hline Rajidae & Leucoraja naevus & 0.183 & 0.298 & & $15 \%$ & Inner and middle shelf \\
\hline Squalidae & Deania calceus & 0.173 & 0.432 & $x$ & & Shelf break \\
\hline Squalidae & Etmopterus spinax & 0.099 & 1.758 & $x$ & & Shelf break \\
\hline Rajidae & Raja undulata & 0.057 & 0.024 & & $x$ & Coastal and inner shelf \\
\hline Squalidae & Scymnodom ringens & 0.045 & 0.129 & $x$ & & Shelf break \\
\hline Myliobatidae & Myliobatis aquila & 0.028 & 0.022 & & $x$ & Coastal and inner shelf \\
\hline Scyliorhinidae & Scyliorhinus stellaris & 0.022 & 0.123 & $x$ & & Inner and middle shelf \\
\hline Hexanchidae & Hexanchus griseus & 0.016 & 0.010 & $x$ & & Middle and outer shelf \\
\hline Torpedinidae & Torpedo marmorata & 0.013 & 0.009 & & $x$ & Coastal and inner shelf \\
\hline Triakidae & Galeorhinus galeus & 0.001 & 0.004 & $x$ & & Inner and middle shelf \\
\hline Triakidae & Mustelus mustelus & 0.001 & 0.004 & $x$ & & Inner and middle shelf \\
\hline Rajidae & Raja brachyura & 0.000 & 0.004 & & $x$ & Coastal and inner shelf \\
\hline Rajidae & Leucoraja circularis & 0.000 & 0.002 & & $x$ & Inner and middle shelf \\
\hline
\end{tabular}



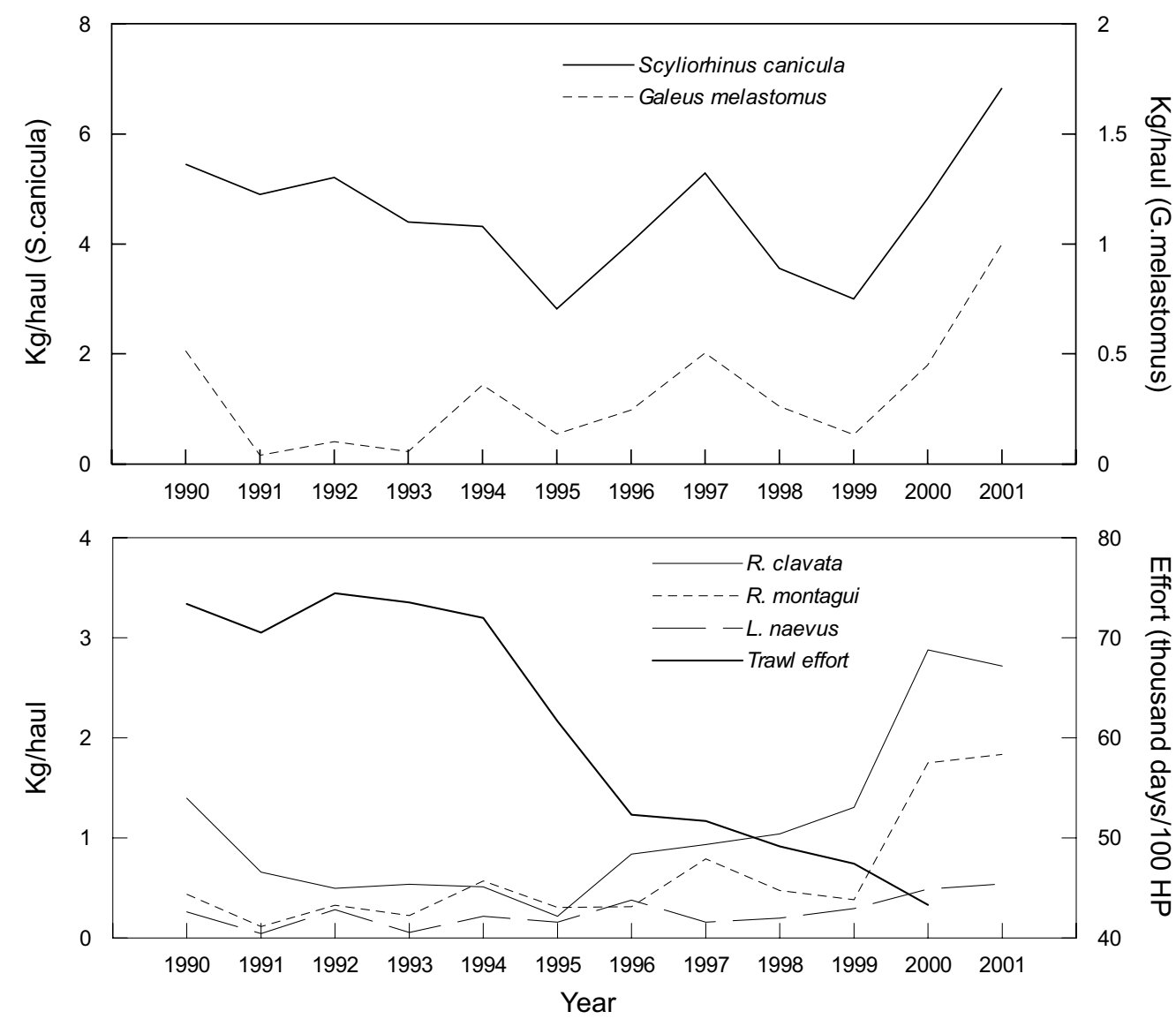

Fig. 2. Bottom trawl surveys biomass indices $(\mathrm{kg} / 30 \mathrm{~min}$ haul) of the main species of elasmobranchs and trawl fishery effort (thousand days by $100 \mathrm{HP}$ ) in the Cantabrian Sea.

are considered have lower trophic levels than the apex predators, being in an intermediate level between the large demersal fish and benthic fish. The ecotrophic efficiency (EE) of elasmobranchs is low compared with the rest of demersal fishes, which means that only 40-60 $\%$ of their production is used within the system. Hence, they are not subjected to strong pressure from predation or fishing. Nearly 1.3 tons per $\mathrm{km}^{2}$ per year is consumed by the two groups of elasmobranchs considered. For the catshark group, this biomass comprises blue whiting (probably discarded), benthic invertebrate carnivores (mainly crustacea) and discards. The opportunistic behaviour of this group of elasmobranchs in taking advantage of feeding on discards from the fleet (2.3 tons per $\mathrm{km}^{2}$ per year estimated), as confirmed by previous studies (Olaso et al., 2002a), and its high survival after being discarded (Rodríguez-Cabello et al., MS 2001) confers many adaptive advantages. For rays, most of the biomass consumed comprises benthic invertebrates carnivores (mainly brachiura crustaceans) and shrimps (natantia crustaceans).
To compare the relative role of the pelagic, demersal and benthic sub-systems, Fig. 3 shows the major biomass flows for the Cantabrian Sea ecosystem in 1994. The groups represented by small plankton, invertebrate filter feeders and detritivores were in trophic level II. Part of their production was transferred to the large plankton, benthic and suprabenthic invertebrates, and clupeiform fish (level III). The planktophagous fish of medium size, together with the rays and benthic fish, were at level IV. The highest level, close to level V, corresponded to apex pelagic fish (tuna), squids, and large demersal and benthic fish.

In the benthic and demersal domain, most of the biomass and production was associated with detritus. Due to the particular primary production blooms pattern of the Cantabrian Sea, feeding pressure on phytoplankton was low in the system $(E E=0.2)$, which meant that a large percentage of this biomass passed to detritus ( 3 064 tons per $\mathrm{km}^{2}$ per year). This is corroborated by studies in the area that indicate that a high percentage 


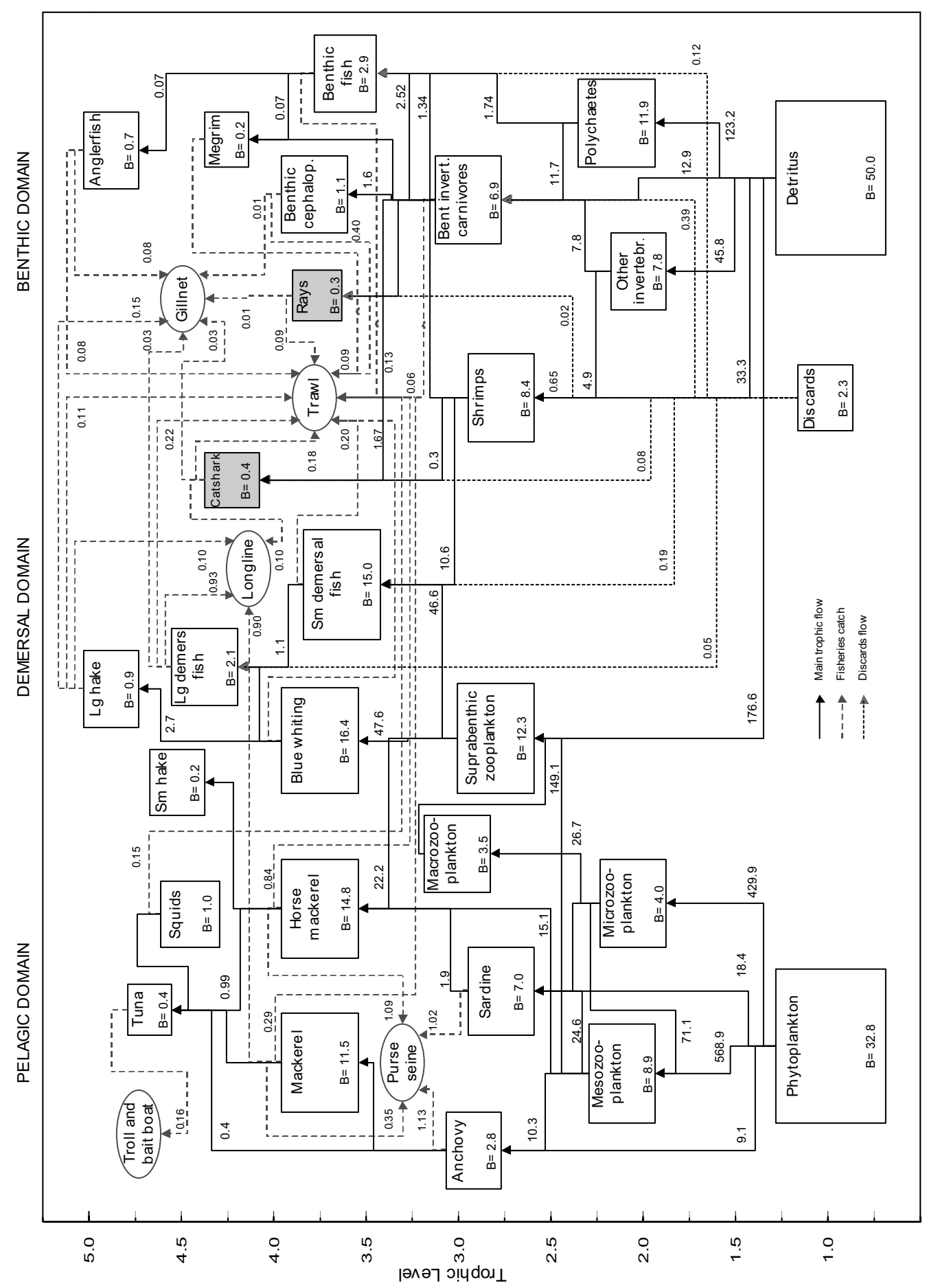

Fig. 3. Main trophic interactions in the Cantabrian Sea, 1994. The boxes are arranged on the y-axis after trophic levels, and to some degree on a pelagic to benthic scale on the $\mathrm{x}$-axis. Only the main flows (trophics, catches and discards flows) are shown expressed in tons per km² $\times$ year $^{-1}$, and the biomass of each trophic group (B) in tons per $\mathrm{km}^{2}$. Minor flows, respiration and all backflows to the detritus are omitted. Each fishery is represented as ellipse (no biomass) in their trophic level. Elasmobranchs trophic groups are highlighted. 
of the primary production is exported to the bottom as particulate organic matter (Bode et al., 1996; Barquero et al., 1998; OSPAR, 2000). The detritus in the model accounted for $19.3 \%$ of total consumption and constituted one of the main energy flow inputs. Hence, detritivorous species were an important component of the Cantabrian Sea ecosystem; suspension feeders (i.e. suprabenthic zooplankton, shrimps) and deposit feeders (polychaetes and other invertebrates) constituted a high percentage of the biomass between trophic levels II and III (Table 2; Fig. 3), in detriment to the pelagic plankton. This has considerable significance for catshark and rays trophic groups since it provides a high quantity of available food (benthic invertebrates and shrimps) making possible a high level of biomass for these elasmobranch groups in this area. Considering the abundance and distribution of elasmobranch species along the north of the continental shelf of the Iberian Peninsula (Sánchez et al.,
1995; 2002) their presence is remarkable high in the Cantabrian Sea. Performing a trophodynamic model in the highly productive Northern Benguela upwelling system, Shannon and Jarre-Teichmann (1999) estimated a chondrichtyans biomass by surface area half that in our study area.

The model shows that the fisheries utilised $36.6 \%$ of the total primary production. This high PPR (primary production requirement) value corroborates the conclusion that the fisheries of the Cantabrian Sea use a large proportion of the productive capacity of the shelf ecosystem (Sánchez and Olaso, 2004). The results indicate a level of fisheries impact in the Cantabrian Sea comparable to the most intensively exploited temperate shelf ecosystems of the world. Similar systems exhibit values of PPR from 24.2 to $35.3 \%$ (Pauly and Christensen, 1995) and 29\% of the primary

TABLE 2. Input values (in italics) and estimates (non italics) of some parameters in the balanced trophodynamic model of 1994 for each trophic group. $\mathrm{TL}=$ Trophic level, $\mathrm{PB}=$ Production/Biomass ratio, $\mathrm{QB}=$ Consumption/Biomass ratio and $\mathrm{EE}$ $=$ Ecotrophic efficiency. Biomass, PB, Food intake, Flow to detritus and Catches (landings + discards) are expressed in tons per $\mathrm{km}^{2}$.

\begin{tabular}{|c|c|c|c|c|c|c|c|c|c|c|c|}
\hline & Group name & $\mathrm{TL}$ & Biomas & $\begin{array}{l}\mathrm{PB} / \\
\text { year }\end{array}$ & $\begin{array}{l}\mathrm{QB} / \\
\text { year }\end{array}$ & $\mathrm{EE}$ & $\begin{array}{l}\text { Food } \\
\text { Intake }\end{array}$ & $\begin{array}{l}\text { Flow to } \\
\text { detritus }\end{array}$ & Catches & $\begin{array}{l}\text { Fishing } \\
\text { mortality }\end{array}$ & $\begin{array}{l}\text { Natural } \\
\text { mortality }\end{array}$ \\
\hline 1 & Tuna & 4.7 & 0.384 & 0.82 & 9.50 & 0.85 & 3.65 & 0.76 & 0.27 & 0.70 & 0.12 \\
\hline 2 & Large hake & 4.7 & 0.876 & 0.53 & 3.90 & 0.79 & 3.42 & 0.78 & 0.37 & 0.42 & 0.11 \\
\hline 3 & Small hake & 4.4 & 0.185 & 0.80 & 6.50 & 0.91 & 1.20 & 0.25 & 0.08 & 0.45 & 0.35 \\
\hline 4 & Anglerfish & 4.8 & 0.746 & 0.38 & 1.90 & 0.56 & 1.42 & 0.41 & 0.16 & 0.21 & 0.17 \\
\hline 5 & Megrim & 4.2 & 0.237 & 0.66 & 3.00 & 0.78 & 0.71 & 0.18 & 0.09 & 0.38 & 0.28 \\
\hline 6 & Large demersal fish & 4.3 & 2.115 & 0.60 & 2.70 & 0.87 & 5.71 & 1.24 & 1.08 & 0.51 & 0.09 \\
\hline 7 & Catshark & 4.0 & 0.330 & 0.25 & 2.50 & 0.42 & 0.83 & 0.22 & 0.04 & 0.11 & 0.15 \\
\hline 8 & Rays & 3.8 & 0.210 & 0.30 & 2.20 & 0.61 & 0.46 & 0.13 & 0.04 & 0.18 & 0.12 \\
\hline 9 & Benthic fish & 3.6 & 2.940 & 1.20 & 2.80 & 0.87 & 8.23 & 2.09 & 0.23 & 0.08 & 1.12 \\
\hline 10 & Blue whiting & 3.8 & 16.415 & 0.48 & 5.30 & 0.93 & 87.00 & 17.90 & 1.50 & 0.09 & 0.39 \\
\hline 11 & Small demersal fish & 3.6 & 15.040 & 1.20 & 6.40 & 0.84 & 96.26 & 22.15 & 0.20 & 0.01 & 1.19 \\
\hline 12 & Horse mackerel & 3.8 & 14.771 & 0.32 & 4.30 & 0.83 & 63.52 & 13.52 & 1.95 & 0.13 & 0.19 \\
\hline 13 & Mackerel & 3.8 & 11.486 & 0.43 & 4.60 & 0.28 & 52.83 & 14.12 & 1.57 & 0.14 & 0.29 \\
\hline 14 & Anchovy & 2.9 & 2.832 & 1.98 & 9.13 & 0.82 & 25.86 & 6.16 & 1.24 & 0.44 & 1.54 \\
\hline 15 & Sardine & 2.8 & 6.978 & 0.58 & 8.80 & 0.60 & 61.41 & 13.92 & 1.58 & 0.23 & 0.35 \\
\hline 16 & Squids & 4.4 & 0.929 & 3.20 & 7.50 & 0.95 & 7.23 & 1.55 & 0.16 & 0.17 & 3.03 \\
\hline 17 & Benthic cephalopods & 3.8 & 1.072 & 3.00 & 6.00 & 0.95 & 6.70 & 1.44 & 0.38 & 0.35 & 2.65 \\
\hline 18 & Benthic invertebrates & 2.9 & 6.564 & 2.60 & 5.60 & 0.95 & 38.72 & 8.25 & 0.13 & 0.02 & 2.58 \\
\hline 19 & Shrimps & 2.8 & 8.263 & 4.20 & 9.67 & 0.95 & 81.63 & 17.76 & 0.02 & 0.00 & 4.20 \\
\hline 20 & Polychaetes & 2.2 & 11.575 & 4.80 & 12.00 & 0.95 & 143.33 & 30.65 & 0.08 & 0.01 & 4.79 \\
\hline 21 & Other invertebrates & 2.1 & 7.642 & 2.50 & 6.50 & 0.95 & 50.99 & 10.93 & 0.25 & 0.03 & 2.47 \\
\hline 22 & Zoopl suprabenthic & 2.7 & 12.192 & 16.00 & 32.00 & 0.95 & 392.36 & 87.84 & 0.00 & 0.00 & 16.00 \\
\hline 23 & Macrozooplankton & 3.1 & 3.483 & 18.00 & 38.00 & 0.95 & 133.25 & 29.62 & 0.00 & 0.01 & 17.99 \\
\hline 24 & Mesozooplankton & 2.2 & 8.889 & 39.08 & 80.00 & 0.99 & 711.12 & 144.25 & 0.00 & 0.00 & 39.08 \\
\hline 25 & Microzooplankton & 2.1 & 3.973 & 45.28 & 120.00 & 0.95 & 477.71 & 104.36 & 0.05 & 0.00 & 45.28 \\
\hline 26 & Phytoplankton & 1.0 & 32.760 & 148.11 & - & 0.21 & 0.00 & 3064.46 & 0.00 & 0.00 & 148.11 \\
\hline 27 & Discards & 1.0 & 2.400 & - & - & 0.98 & 0.00 & 0.03 & 0.00 & 0.00 & 0.00 \\
\hline 28 & Detritus & 1.0 & 50.000 & - & - & 0.13 & 0.00 & 0.00 & 0.00 & 0.00 & 0.00 \\
\hline
\end{tabular}


production is required to sustain the catches in the North Sea ecosystem (Christensen, 1995). The catshark and ray mortality estimates obtained from the model indicate very low values for both the $F$ and $M$ (Table 2). A preliminary assessment of these species carried out under the DELASS project using VPA(ICES, MS 2002a) gave even lower values of $F(0.04)$. However, in the VPA analysis, only landings were taking into account, not the true catch (including discards) which accounts for much of the fishing mortality. On the other hand, Ecopath uses the catch but does not take account of the high percentage of $S$. canicula discarded that survive (78\% estimated by Rodriguez-Cabello et al., MS 2001), which might overestimate the fishing mortality. A study by Pérez et al., (1996) estimated that the percentage of discards made by the trawl fleet in this area for catsharks and rays were about $80-90 \%$ and $20-30 \%$, respectively. Because the estimations of total biomass and landings of elasmobranchs species are not as precise as they should be, the model outcomes must be considered as preliminary.

\section{Mixed Tropic Impacts}

Figure 4 shows the mixed trophic impacts of different groups and fisheries using the Leontief matrix. This analysis allows estimation of the relative impact of a change in the biomass of one group on other components of the ecosystem, under the assumption that the diet composition remains constant (Ulanowicz and Puccia, 1990). The impacts produced by catshark and rays have rather low values compared with the impacts that other trophic groups have on them. The lack of predators on elasmobranchs make fisheries the highest negative impact on them.

For catshark (Fig. 4A), only low notable negative impact is produced on small hake, on megrim, on its own intraspecific competition (considering its high abundance), and on the discards (by consumption). The most important negative impact on catshark is that produced by the commercial trawl fishery and, to a lesser extent, by the longline fishery; these are the main causes of its total mortality. For living trophic groups, large demersal fish, benthic fish and benthic cephalopods have a high percentage of prey overlap $(80 \%, 70 \%$ and $60 \%$, respectively, Table 3 ) and have negative impacts on catshark. It is likely that the groups of small demersal fish and horse mackerel have also a negative impact since they consume large quantities of suprabenthic zooplankton, one of the main prey of juvenile catshark. Finally, it is significant that there are positive impacts on the catshark populations from benthic invertebrate carnivores, the discards (important in its diet), and the detritus (the food of many of their prey).
The rays group (Fig. 4B) is subject to more impacts than the small sharks. The positive impacts are caused by their common prey (mainly detritivorous organisms) and the discards and detritus, similar to those of catshark. The trawl fishery has a very negative effect, at a higher level than for small sharks, as is the case of the gillnet fishery. Many other trophic groups compete with rays, like their main food competitors (benthic cephalopods, 90\% prey overlap) and all the components of the main trophic flow pelagic-demersal (phytoplankton->mesozooplankton-> suprabenthic zooplankton- $>$ small demersal fish->blue whiting). These outcomes indicate that the ecosystems whose production is based on phytoplankton and the pelagic trophic net (upwelling areas) do not benefit rays. On the other hand, the ecosystems with high level of detritus flow (as for the Cantabrian Sea) are more appropriate.

Trawl fishing effort has been reduced in recent years (ICES, MS 2002b and Fig. 2). Considering that the impact caused by the trawl fishery is the major limiting factor on the catshark and ray populations, according to MTI analysis, the effort reduction might have been responsible for the biomass index increase reflected in the different elasmobranchs groups in the study area (Fig. 2).

\section{Temporal and Spatial Simulations}

Simulations and projections with Ecosim with different trawl fishing regimes, starting from the present model of 1994 inputs, are used. For wider ranges of $F$, the basic Ecosim output is the relationship between equilibrium biomasses, catch and fishing rates. Rays and catshark (large-bodied species with low rates of turn-over), anglerfish, megrim (trawl catch only), hake (strong trawl effect on juveniles), benthic cephalopods and large demersal fish are the main trophic groups, which increased their biomass when trawl fishing decreased. Horse mackerel, small demersal fish, sardine and anchovy (populations with high rates of turnover and planktophagous food preferences) are not affected by the different values of trawl regimes. Furthermore, scavenging species, such as benthic invertebrate carnivores, are not affected by different trawl regimes. Ecospace predictions of steady-state biomass densities in the base-map of the central Cantabrian Sea scenario during 5-year simulation (including the effect of a closed area to trawling) show that in a closed area, the biomass levels of rays, catshark, large demersal fish, benthic fish, small demersal fish and benthic cephalopods are higher than in adjacent areas (Fig. 5). Also, the trawl exclusion in this area reduces the biomass of small pelagic fish (anchovy and sardine), blue whiting (more pressure from predators), megrim and values for discards. 

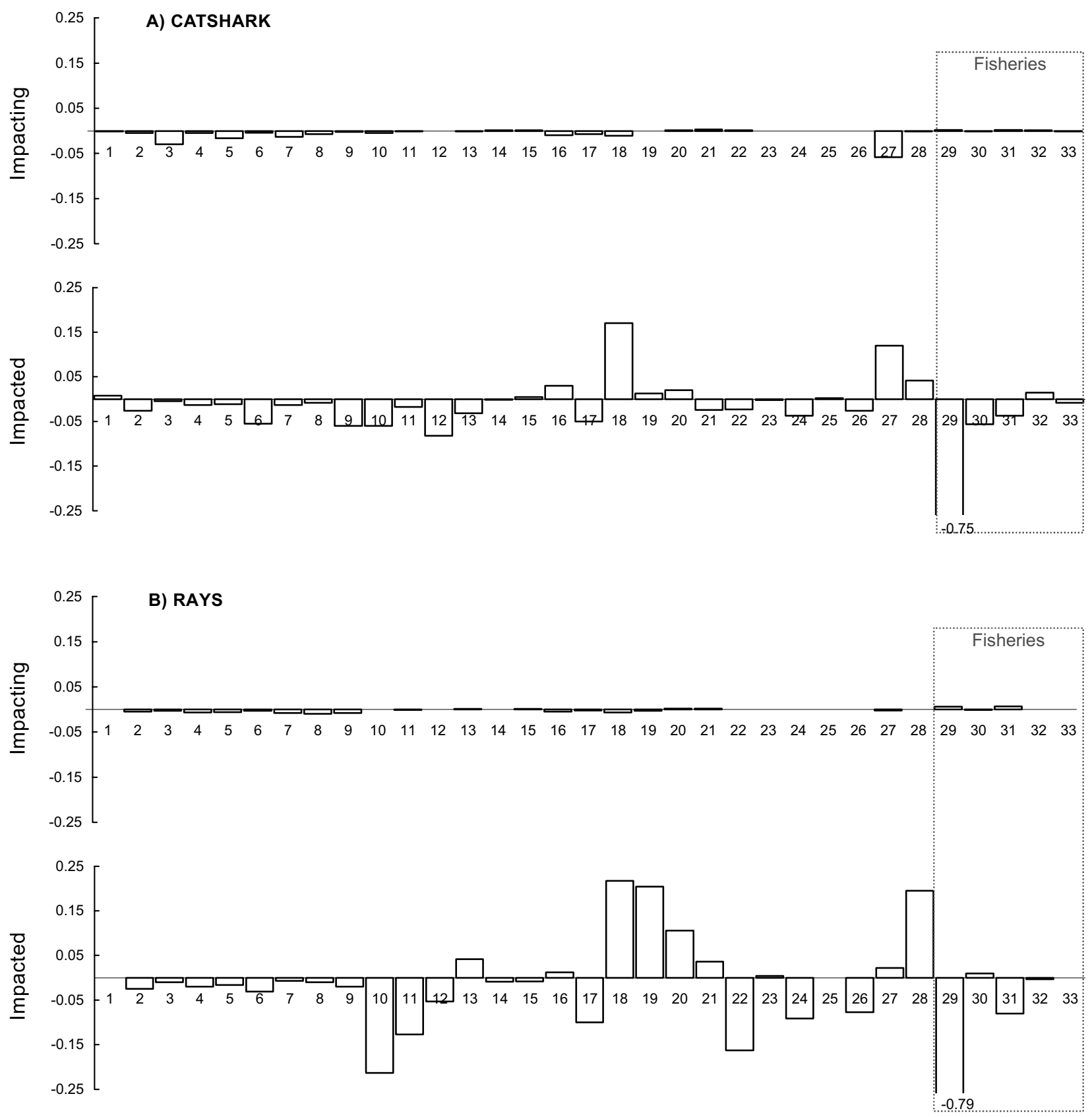

\begin{tabular}{|c|c|c|c|c|}
\hline 1 Tuna & 8 Rays & 15 Sardine & 22 Suprab. zooplk. & 29 Trawl \\
\hline 2 Large hake & 9 Benthic fish & 16 Squids & 23 Macrozooplk. & 30 Longline \\
\hline 3 Small hake & 10 Blue whiting & 17 Benthic cephalopods & 24 Mesozooplk. & 31 Gillnet \\
\hline 4 Anglerfish & 11 Small demersal fish & 18 Benthic invert. carniv. & 25 Microzooplk. & 32 Seine \\
\hline 5 Megrim & 12 Horse mackerel & 19 Shrimps & 26 Phytoplankton & 33 Troll and \\
\hline 6 Large demersal fish & 13 Mackerel & 20 Polychaetes & 27 Discards & bait boat \\
\hline 7 Catshark & 14 Anchovy & 21 Other invertebrć & 28 Detritus & \\
\hline
\end{tabular}

Fig. 4. Mixed trophic impacts using the Leontief matrix. The computed impacts are relative on a scale from -1 to 1 , where 0 indicates no impact, but comparable between groups. The bars quantify the direct and indirect trophic impacts that the groups Catshark (A) and Rays (B) have on the groups listed at the bottom and vice versa. 


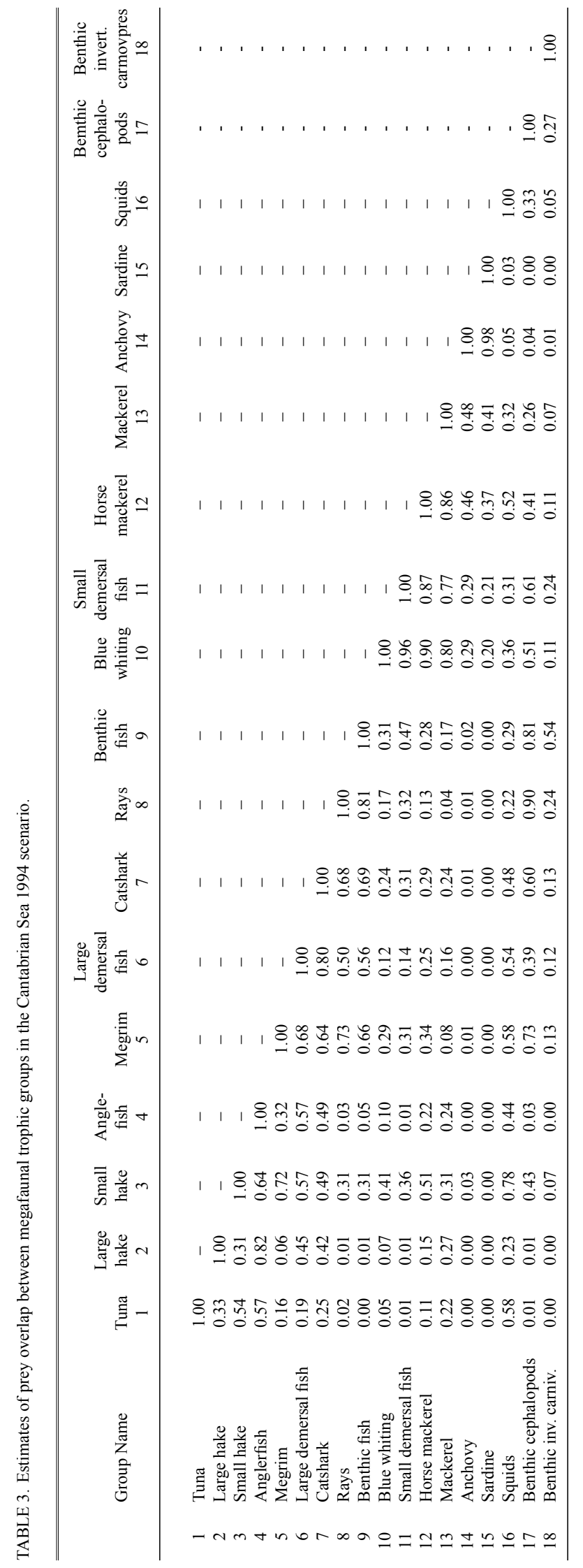


Figure 6 shows the time series of bottom trawl surveys abundance indices $(\mathrm{kg} / 30 \mathrm{~min}$. haul) by trophic group for the Llanes closed area. The main fish species groups that gain benefit from the trawl exclusion are elasmobranchs (catshark and rays), small demersal fish (e.g. Pagellus, Boops), benthic fish (mullet, gurnards and great weever). Also, benthic cephalopods (octopus and white octopus) and other invertebrates (sea urchins) groups show major increases in the level of biomass in the Llanes closed area after closure to trawl operations. In general, validation of the trophodynamic model, using abundance indices from surveys, suggests that the simulations provided by Ecospace are realistic.
The demersal elasmobranchs groups considered in the present study do not make long migrations (Rodríguez-Cabello et al., 1998) and have a tendency to remain in the same area if the conditions suit them. Studies carried out in the North Sea reveal that rays $(R$. clavata) do not make extensive migrations, tagged rays remain within 50-60 km from the site of tag and release (Walker et al., 1997). Elasmobranchs are considered typically $k$ selected. They have low growth, late sexual maturity, produce relatively few offspring with low natural mortality after their long reproductive cycles, and are long-lived. These characteristics make catshark and rays sensitive to changes in the areas influenced
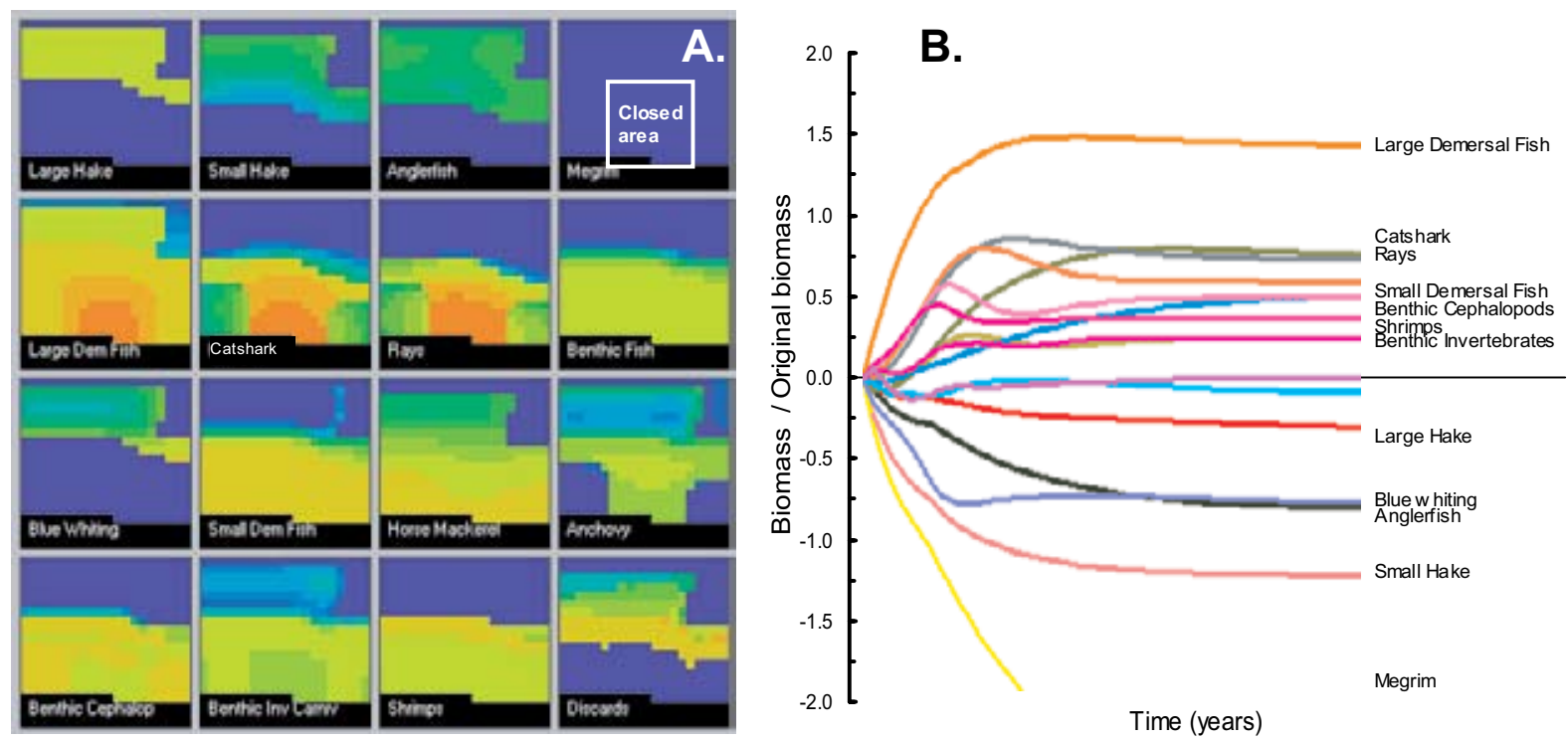

Fig. 5. (A) Five years Ecospace simulation using the effect of trawl closed area in the central Cantabrian Sea scenario. (B) Results for biomass of different trophic groups (values are relative to the start situation).
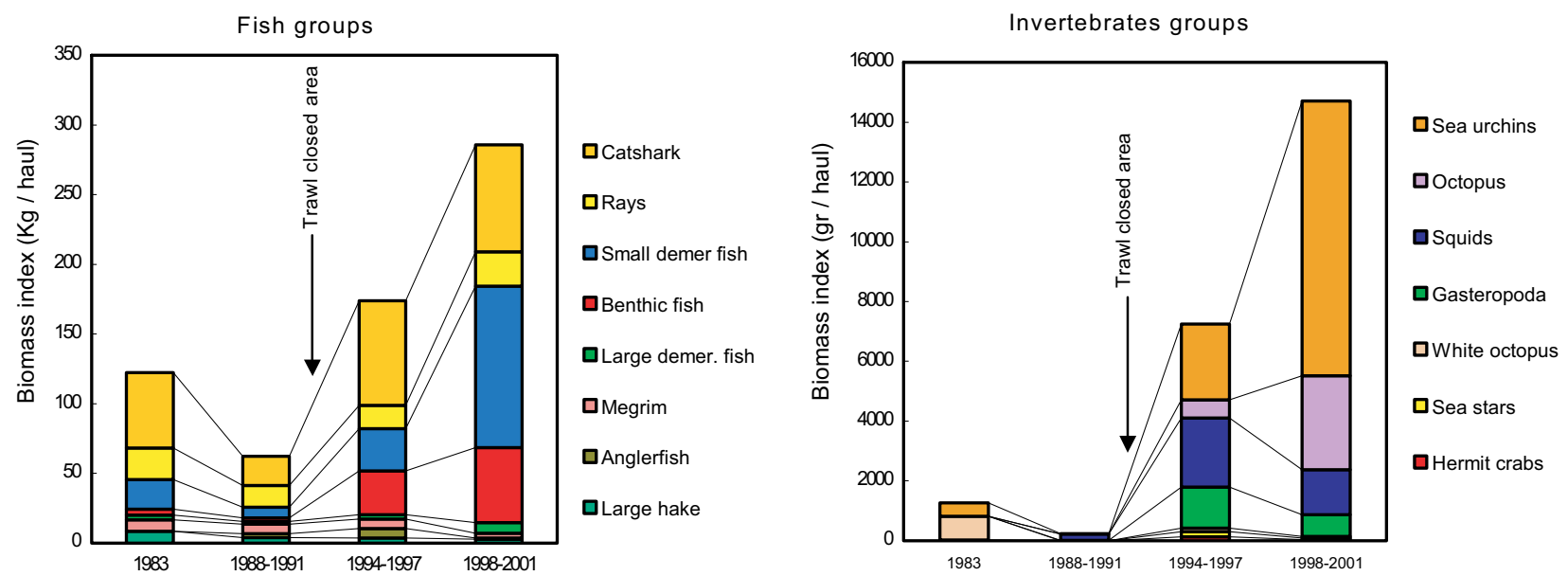

Fig. 6. Bottom trawl survey indices of main fish ( $\mathrm{kg} / \mathrm{haul})$ and invertebrates (gr/haul) groups in the $\mathrm{L}$ lanes trawl closed area. The period 1983-91 was before closure and the period 1994-2001 was after closure of trawlers operations. 
by fishing. We know that the catch of elasmobranchs in many fisheries has increased or fallen due to the mortality caused by fishing activities (ICES, MS 1995; Pratt and Casey, 1990; Sánchez et al., MS 1998). For this reason, the benefits of the marine protected areas on elasmobranchs, increasing the biomass, are obvious.

\section{Conclusions}

The Cantabrian Sea ecosystem, because of its peculiar characteristics (ground types, primary production mechanisms, trophic net, and artisanal fisheries), with a notable importance of the demersal and benthic domains, is favourable to the presence of demersal and benthic elasmobranchs.

The capacity of catshark to survive long periods of emersion and consequently to be alive after being discarded, together with the advantage of feeding on discards in an intensively exploited area, provides these species with a lot of adaptive benefits.

Controls implemented by policy makers to restrict trawlers to grounds $<100 \mathrm{~m}$ deep, and the establishment of anti-trawling devices (artificial reefs) in certain areas from 1993 have enabled a notable recovery in the populations of catshark and rays.

The main cause of the recovery of elasmobranchs during recent years can be attributed to reduced fishing mortality associated with a reduction of the trawl fishing effort.

In an ecosystem heavily exploited by multispecies fisheries, as in the Cantabrian Sea, the present management system based on total allowable catches (TACs) and quotas regimes, with a very low number of species under assessment, is not suitable for sustaining the elasmobranchs species. A management measure based on the control and reduction of the fishing effort and the establishment of certain areas closed to some fisheries is a better approach for a global management in the ecosystem context.

Unfortunately, the lack of information on biomass, food preferences, production, fisheries of the small deep water sharks that inhabit the break shelf have hindered creation of another trophic group of sharks. The existence in the study area of a longline fishery targeting these species and the peculiarities of this important group of elasmobranchs, which is very sensitive to the fishing pressure, requires that a research effort must be undertaken to estimate its status and establish appropriate management measures.

\section{Acknowledgements}

We thank all the Instituto Español de Oceanografia (IEO) colleagues who contributed to the trawl surveys, stomach analysis, fisheries database, and those responsible for the ICES stock assessment working groups for their excellent work that made it possible to obtain a valuable source of input data for the Cantabrian Sea ecosystem. A part of this study was carried out through participation of the authors in the European DELASS project, funded by the European Commission (DG XIV, study No. 99/55).

\section{References}

BARQUERO, S., J. A. CABAL, R. ANADÓN, E. FERNÁNDEZ, M. VARELA, and A. BODE, 1998. Ingestion rates of phytoplankton by copepod size fractions on a bloom associated with an off-shelf front off NW Spain. J. Plankton Res., 20(5): 957-972.

BODE, A., B. CASAS, E. FERNÁNDEZ, E. MARAÑÓN, P. SERRET, and M. VARELA, 1996. Phytoplankton biomass and production in shelf waters off NW Spain: spatial and seasonal variability in relation to upwelling. Hydrobiologia, 341: 225-234.

CHRISTENSEN, V., 1995. A model of trophic interactions in the North Sea in 1981, the Year of the Stomach. Dana, 11(1): 1-28.

CHRISTENSEN, V., and D. PAULY. 1992. ECOPATH II - a software for balancing steady-state models and calculating network characteristics. Ecol. Model., 61: 169-185.

1993. On Steady-State Modelling of Ecosystems. In: Models of Aquatic Ecosystems. V. Christensen and D. Pauly (eds.). Trophic ICLARM Conf. Proc., 26: 14-19.

ICES, MS 1995. Report of the Study Group of elasmobranch fishes. ICES C.M. Doc., No. G:3, 88 p.

MS 2002a. Report of the study group on elasmobranch fishes. Copenhagen, 6-10 May 2002. ICES C.M. Doc., No. G:08 ref. ACFM.

MS 2002b. Working Group on the Assessment of Southern Shelf Demersal Stocks. ICES C.M. Doc., No. ACFM:05.

MS 2002c. Report of the Working Group on the Assessment of Mackerel, Horse Mackerel, Sardine and Anchovy. ICES C.M. Doc., No. ACFM:06.

OLASO, I., 1990. Distribución y abundancia del megabentos invertebrado en fondos de la plataforma Cantábrica. Publ. Espec. Inst. Esp. Oceanogr., 5: 128 p.

OLASO, I., F. SÁNCHEZ, C. RODRÍGUEZ-CABELLO, and F. VELASCO, 2002a. The feeding behaviour of some demersal fish species in response to artificial discard. Sci. Mar., 66(3): 301-311.

OLASO, I., F. VELASCO, and N. PÉREZ, 1998. Importance of blue whiting (Micromesistius poutassou) discarded in the diet of lesser-spotted dogfish (Scyliorhinus canicula) in the Cantabrian Sea. ICES J. Mar. Sci., 55: 331-341.

OLASO, I., F. VELASCO, F. SÁNCHEZ, A. SERRANO, 
C. RODRÍGUEZ-CABELLO, and O. CENDRERO. 2004. Trophic relations of lesser spotted dogfish (Scyliorhinus canicula) and black mouth dogfish (Galeus melastomus) in the benthic and demersal communities of the Cantabrian sea. J. Northw. Atl. Fish. Sci., 35: 375-385 (this volume).

OSPAR., 2000. Quality Status Report 2000. Region IV - Bay of Biscay and Iberian coast. OSPAR Commission, London, $134+$ xiii $\mathrm{p}$.

PAULY, D., and V. CHRISTENSEN, 1995. Primary production required to sustain global fisheries. Nature, 374: 255257.

PAULY, D., V. CHRISTENSEN, and C. J. WALTERS, 2000. Ecopath, Ecosim and Ecospace as tools for evaluating ecosystem impacts of fisheries. ICES J. Mar. Sci., 57: 697-706.

PÉREZ, N., P. PEREDA, A. URIARTE, V. TRUJILlO, I. OLASO, and S. LENS, 1996. Descartes de la flota española en el área del ICES. Datos y Resúmenes. Instituto Español de Oceanografía, Núm. 2, 142 p.

POLOVINA, J. J., 1984. Model of a coral reef ecosystem I. The ECOPATH model and its application to French Frigate Shoals. Coral Reefs, 3: 1-11.

PRATT, H., and J. G. CASEY, 1990. Shark Reproductive Strategies as a Limiting Factor in Directed Fisheries, with a Review of Holden's Method of Estimating Growth-Parameters. In: Elasmobranchs as Living Resources: Advances in the Biology, Ecology, Sistematics, and the Status of the Fisheries. H. Pratt, S. Gruber and T. Tanuchi (eds.). NOAA Tech. Report., 90: 97-109.

RODRÍGUEZ-CABELLO, C., F. DE LA GÁNDARA, and F. SÁNCHEZ, 1998. Preliminary results on growth and movements of dogfish (Scyliorhinus canicula, Linnaeus, 1758) in the Cantabrian Sea. Oceanologica Acta, 21(2): 363-370.

RODRÍGUEZ-CABELLO, C., A. FERNÁNDEZ, I. OLASO, and F. SÁNCHEZ, MS 2001. Survival of lesser-spotted dogfish (Scyliorhinus canicula, L.) discarded by trawlers. ICES C.M. Doc., No. N:06, 10 p.

RODRÍGUEZ-CABELLO, C., A. FERNÁNDEZ, I. OLASO, and F. SÁNCHEZ, R. GANCEDO, A. PUNZON, and O. CENDRERO. 2004. Overview of continental shelf elasmobranch fisheries in the Cantabrian Sea. J. Northw. Atl. Fish. Sci., 35: 375-385.

SÁNCHEZ, F., 1993. Las comunidades de peces de la plataforma del Cantábrico. Publ. Espec. Inst. Esp. Oceanogr. 13: $137 \mathrm{p}$.

SÁNCHEZ, F., M. BLANCO, and R. GANCEDO, 2002. Atlas de los peces demersales y de los invertebrados de interés comercial de Galicia y el Cantábrico. Otoño 1997-1999. Ed. CYAN (Inst. Esp.Oceanogr.), 158 p.
SÁNCHEZ, F., F. DE LA GÁNDARA, and R. GANCEDO, 1995. Atlas de los peces demersales de Galicia y el Cantábrico, Otoño 1991-1993. Publ. Esp. Inst. Esp.Oceanogr. 20: $99 \mathrm{p}$.

SÁNCHEZ, F., and J. GIL. 2000. Hydrographic mesoscale structures and Poleward Current as a determinant of hake (Merluccius merluccius) recruitment in southern Bay of Biscay. ICES J. Mar. Sci., 57: 152-170.

SÁNCHEZ, F., and I. OLASO, 2001. Cantabrian Sea ecosystem model and fishery resources management. Oceanographie du Golfe de Gascogne, Ed. Ifremer, Actes Colloq., 31: 187-194.

2004. Effects of fisheries on the Cantabrian Sea shelf ecosystem. Ecological Modelling, 172: 151-174.

SÁNCHEZ, F., I. OLASO, and R. GOÑI. MS 1998. Changes in bottom trawl survey catch rates in dogfish (Scyliorhinus canicula) and Thornback ray (Raja clavata) in the Cantabrian sea between 1983 and 1997. In: Report of the Working Group of Ecosystem Effects of Fishing, ICES C.M. Doc., ACFM/ACME:1, Ref.:E:1, 263 p.

SÁNCHEZ, F., and A. SERRANO, 2003. Variability of groundfish communities of the Cantabrian Sea during the decade of the 1990s. ICES Marine Science Symposia, 219: 249-260.

SHANNON, L.J., and A. JARRE-TEICHMANN, 1999. A model of trophic flows in the Northern Benguela upwelling system during the 1980s. South African Journal of Marine Science, 21: 349-366.

ULANOWICZ, R.E., and C. J. PUCCIA, 1990. Mixed trophic impacts in ecosystems. Coenoses, 5(1): 7-16.

VELASCO, F., I. OLASO, and A. SERRANO, 2002. Alimentación de tres especies de la familia Rajidae en el sur del Golfo de Vizcaya. Actas del $8^{\circ}$ International Symposium on Oceanography of the Bay of Biscay, Gijón, April 2002.

WALKER, P., 1998. Fleeting images: Dynamics of Ray populations in the North Sea. Doctoral Thesis, University of Amsterdam. 143 p.

WALKER, P., G. HOWLETT, and R. MILLNER, 1997. Distribution, movement and stock structure of three ray species in the North sea and eastern English Channel. ICES, J. of Mar. Sci., 54: 797-808.

WALTERS, C., V. CHRISTENSEN, and D. PAULY, 1997. Structuring dynamic models of exploited ecosystems from trophic mass-balance assessments. Reviews in Fish Biology and Fisheries, 7: 139-172.

WALTERS, C., D. PAULY, and V. CHRISTENSEN, MS 1998. Ecospace: prediction of mesoscale spatial patterns in trophic relationships of exploited ecosystems, with emphasis on the impacts of marine protected areas. ICES C.M. Doc., 1998. Theme Session (S), 22 p. 